\title{
Critical Wounds, Sutured
}

Veprinska, Anna. Empathy in Contemporary Poetry after Crisis. London: Palgrave

\section{Macmillan, 2020. 203 pages. ISBN 978-3-030-34319-4. Hb. €74.89.}

Imre Olivér Horváth

https://doi.org/10.30608/HJEAS/2021/27/2/19

How are we affected by the pain of others after humanitarian crises that call our humanity into question? How do we relate to their plight if empathizing with them always involves some degree of appropriation? If empathy is both the "thread and needle" of social life (with the power to both connect and hurt), how does writing after crises reflect this ambiguity? Anna Veprinska tackles these very questions in her 2020 volume, her first academic book, which is also the first ever to offer an account on empathy in contemporary poetry after humanitarian crises. She analyzes poems "whose focus on pain has the potential to offer insight into the concept of empathy itself" (31).

A Social Sciences and Humanities Research Council Postdoctoral Fellow at the University of Toronto, Veprinska has published articles on poetry, trauma, and empathy. Nevertheless, her interest in poetry is not only academic: she is also a poet in her own right, having published a full-length collection of poetry, titled Sew with Butterflies (Steel Bananas, 2014) and a brand-new chapbook Spirit-clenched (Gap Riot, 2020). She has also taught courses in English at York University and Seneca College and creative writing at Poetry School, a nationwide organization. A multi-faceted practitioner of poetry, she has an interdisciplinary approach to empathy, relying on "philosophy (Hume, Adam Smith, Goldie, Spelman, Butler), psychology (Katz, Wispé, Tangney, and Dearing), cultural theory (Boyarin, Kaplan), history and literary theory (Solnit, Brecht, S. Hartman), and trauma studies (Caruth, LaCapra)" (31). She addresses the empathetic poetry that reflects on crises, namely, the Holocaust, 9/11, and 
Hurricane Katrina, poems that "variously enact, invite, refuse, evoke, deploy, condemn, show interest in, and/or ambivalence toward empathy" (3), a phenomenon she terms "empathetic dissonance."

In the Introduction, Veprinska takes into account the numerous problems that come with the study of empathy. Partly because of its historical contingency, the term "empathy" overlaps with concepts like pity, kindness, sympathy, and compassion. Instead of the futile task of disentangling these, Veprinska is "interested in how these terms and theories complement and interrogate each other" (13). Accordingly, she defines empathy as an open space between the giver and receiver of empathy, where "feeling and imagination are free to roam between both participants in a reciprocal process" (13), while also leaving it open to the existing definitions. She then carefully and exhaustively lists the dangers of empathy, which seem to significantly outweigh its benefits. She touches upon various issues, most of which connected to the power relations between the parties, including the problem of empathetic appropriation (the speaker's denial of anger in Susan Birkeland's "Jesus Poem," for example), as well as the limits of empathy. After twenty-five pages of barely mentioning poetry, Veprinska briefly discusses the reasons why poetry is especially suitable for the study of empathy. The characteristics she considers, mainly those related to poetry's distance from the reader (figurative language, multiplicity of meaning, required investment of time) and to poetry being an event (like a testimony) are convincing, but this section would have been more appropriate as the starting point of the Introduction.

The first chapter, titled "The Unsaid," examines what is unspeakable or omitted from the poems analyzed, as well as what, rhetorically speaking, is expressed, with the conclusion that all the poems - from Ursula Duba's "Who Knew the Murders," which poses a series of unanswered questions, to Jean Valentine's "In the Burning Air," which omits references to 9/11, or to Niyi Osundare's "Now This," which makes use of two ellipses —invite as well as 
question empathy. The second chapter, "The Unhere," looks at poetic witnesses that are both present and remote, who can only enter the common ground of empathy indirectly, through archival materials. Charles Reznikoff's long poem, Holocaust (1975), for example, relies on war documents and testimonies, among other items. Similarly, Wisława Szymborska's ekphrastic "Photograph from September 11" describes Richard Drew's The Falling Man and Claudia Rankine's Citizen: An American Lyric (2014), and builds on quotes from CNN. "The Ungod," the closing chapter, analyzes poems in which it is God that is both present and absent. Paul Celan's “Tenebrae” acknowledges God but refuses to worship him; Katie Ford's "Flee” suggests the (non)presence of God by way of a light that is unable or unwilling to help; Dan Pagis's “Autobiography” resorts to Biblical figures that evoke God by proxy. The categories of "unsaid," "unhere," and "ungod" are all indicative of the simultaneous affirmation and denial of the underlying phenomena they focus on, and are therefore empathetically dissonant.

Although the structure of the volume may appear to be somewhat unusual, it is fairly effective. Instead of elaborating on the Holocaust, 9/11, and Hurricane Katrina poems in separate chapters, Veprinska chooses to keep them in focus all through the book, by offering different points of departure for her analyses in line with the notions manifest in the titles of the three chapters. This not only shows that the "unsaid," the "unhere," and the "ungod" are all inescapably relevant to the poetry following the traumatic experiences the poets were, directly or indirectly, exposed to, but allows the poems about the different disasters to speak to each other. However, the choice of starting with the Holocaust and ending with Hurricane Katrina in the chapters, as she reluctantly admits, might give the illusion of a hierarchical relationship between the cataclysms in question (185). The Holocaust is definitely given priority over the other two, but this is partly because the Holocaust sections arguably discuss the most compelling poems (Paul Celan's, for example). When Veprinska considers poems of varied quality (Susan Birkeland's "Jesus Poem," for instance, is definitely a low point), she does so 
deliberately, and her choices are justified by the respective topics of the chapters. Her reading of the poems, moreover, is consistently excellent, and her argument is easy to follow: the longish paragraphs typically end with a sentence that reiterates her claim and draws a conclusion.

Veprinska's most fascinating interpretations are related to the poets' use of pronouns, all of which point to empathetic dissonance. Charlotte Delbo's untitled poem from None of Us Will Return (1965), for instance, “coerces the ignorant 'you' into occupying the camp detainee's subject position" (50) by referring to both addressee and detainee as "you." In Lily Brett's "Leaving You," similarly, the speaker's repeated use of the first-person singular pronoun "obliterates the presence of the second person - pronoun and mother - throughout the majority of the poem" (106) to distance herself from her mother's traumatic experiences she inherited. The dedication poem to Marlene Green in Cynthia Hogue and Rebecca Ross's When the Water Came: Evacuees of Hurricane Katrina (2010), furthermore, "draws a sharp line between the questioning 'they' and the resolute 'we' .... Denying foreigners the ability to understand residents . .., Green also denies those who are geographically unhere the ability to empathize" (123). Examples of these and other exploitative uses of pronouns are discussed in almost all subchapters. They stand witness to Veprinska's truly attentive close reading, which is where her book is at its best.

As for her theoretical contribution (besides the notion of empathetic dissonance), Veprinska considers the various ways knowledge is brought into play in the common field of empathy. Relying on clinical psychologists June Price Tangney and Ronda L. Dearing, she accentuates both the affective and cognitive aspects of empathy, which correspond to feeling and imagination in poetry (13). The emphasis here falls on the cognitive quality. In Ursula Duba's "Who Knew the Murderers," the speaker suspects her ancestors are perpetrators of genocide, so "doubt disturbs the empathy that the speaker feels for her family members" (57). 
While Jean Valentine's “In the Burning Air" does not directly refer to 9/11, the titular image "metonymically suggests the familiar, internationally televised image of the burning World Trade Centers" (68), thereby appealing to the indirect knowledge of the public. In Claudia Rankine's Hurricane Katrina section in Citizen: An American Lyric, the repeated question "Have you seen their faces?" suggests that the largely African-American victims are "unacknowledged by the oppressive social and political forces that Rankine's poem critiques" (130). That is to say, Veprinska's approach extends Judith Butler's concept of "grievable life," claiming that "empathy operates through bias and restriction" (16).

Empathy in Contemporary Poetry after Crisis is a highly engaging book, both because of and despite its unusual structure. It is true, however, that one might find the Introduction particularly strange, due to the fact that instead of considering poetry as such, it chooses to concentrate on empathy in general. The book does not aim to introduce the reader to the poetry written in the wake of crises from the point of view of literary history or literary theory; it does, however, discuss empathy through a selection of relevant poems, using a wide variety of approaches to the central theme. Veprinska explores their complexities and vicissitudes very effectively and in great detail, paying attention to power dynamics, to the social, racial, and class relations in which the poems are embedded, as well as the subtle differences between the crises in question. While emotionally demanding, the book is intellectually rewarding: always relying on the texts, Veprinska's highly thorough close readings of the poems, as well her approach of emphasizing both the emotional and the cognitive factors of empathy, are bound to grab and hold the reader's attention, and make the book a delight to read. 